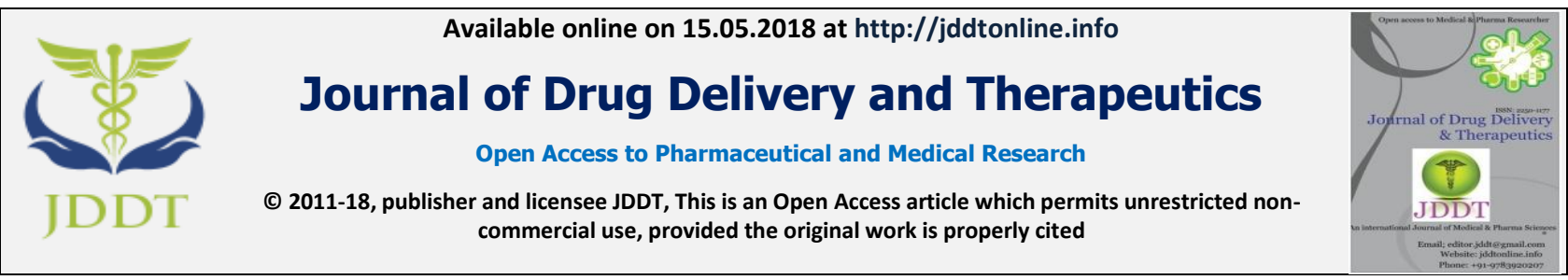

Open $\odot$ Access

Research Article

\title{
THE EFFECT OF OMEGA® ROOTS + GINSENG ALOE VERA, A NIGERIAN HERBAL MIXTURE, ON HAEMATOLOGICAL PARAMETERS OF NORMAL EXPERIMENTAL RATS
}

\author{
Emuesiri Goodies Moke ${ }^{1 *}$, Ighohwo Oghoghovwe ${ }^{2}$, Ejiroghene Ahante ${ }^{3}$ \\ ${ }^{1}$ Department of Pharmacology and Therapeutics, Delta State University, Abraka, Delta State, Nigeria \\ ${ }^{2}$ Department of Radiography, University of Calabar, Calabar, Cross River State, Nigeria \\ ${ }^{3}$ Department of Pharmacology and Toxicology, University of Benin, Benin City, Edo State, Nigeria
}

\begin{abstract}
Omega ${ }^{\circledR}$ Roots + Ginseng Aloe Vera herbal mixture is a commonly sold herbal formulation used for treatment of ailments. The aim of this study is to evaluate the toxic effect of Omega ${ }^{\circledR}$ Roots herbal mixture on the haematological parameters of Wistar rats. Twenty rats were used for this study and were divided into four groups of 5 animals each; the control group was administered normal saline $10 \mathrm{ml} / \mathrm{kg}$, and the treated groups received $250 \mathrm{mg} / \mathrm{kg}, 500 \mathrm{mg} / \mathrm{kg}$, and $1000 \mathrm{mg} / \mathrm{kg}$ of the herbal mixture (Omega ${ }^{\circledR}$ Roots) a period of fourteen days after which blood samples were collected for haematological analysis. The results of this study showed that oral administration of the Omega ${ }^{\circledR}$ Roots extract had a non-significantly $(\mathrm{P}>0.05)$ change in the red blood cell count, white blood cell count, packed cell volume, and hemoglobin concentration of the Wistar rats. The findings suggest that Omega ${ }^{\circledR}$ Roots + Ginseng Aloe Vera herbal mixture is non-haematotoxic following acute administration.
\end{abstract}

Keywords: Omega ${ }^{\circledR}$ Roots, herbal mixture, non-haematotoxic, phytomedicine.

Article Info: Received 12 March, 2018; Review Completed 12 April 2018; Accepted 14 April 2018; Available online 15 May 2018

Cite this article as:

Moke EG, Oghoghovwe I, Ahante E, The effect of Omega $®$ roots + Ginseng Aloe Vera, a Nigerian herbal mixture, on haematological parameters of normal experimental rats, Journal of Drug Delivery and Therapeutics. 2018; 8(3):29-31 DOI: http://dx.doi.org/10.22270/jddt.v8i3.1742

*Address for Correspondence:

Emuesiri Goodies Moke, Department of Pharmacology and Therapeutics, Delta State University, Abraka, Delta State, Nigeria.

\section{INTRODUCTION}

Over time, plant parts such as seeds, berries, roots, leaves, barks, and flowers have been used in the practice of herbal medicine, also called botanical medicine or phytomedicine. Folklore medicine has grown to be recognized as of great health importance to the health of individuals and communities. Traditionally, a good number of medicinal plants are employed to alleviate ailments. ${ }^{1}$ They have been used for centuries as remedies for human diseases because they contain components of therapeutic value. ${ }^{2}$ In recent times, focus on plant research has increased all over the world and a large body of evidence has been collected to show immense potential of medicinal plants used in various traditional systems. $^{3}$ In Nigeria, like other countries, several numbers of plants species have been investigated to possess medicinal properties and employed in the treatment of many ailments. ${ }^{4}$ Despite herbal medicine gaining much popularity and usage, there is the need to assess the level of its toxicity following use. ${ }^{5,6}$ Also, associated with herbal decoctions usage are potential adverse effects, especially in chronic conditions, due to bioaccumulation and altered detoxification processes. ${ }^{7}$

Omega ${ }^{\circledR}$ Roots + Ginseng Aloe Vera herbal mixture (Omega ${ }^{\circledR}$ Roots) commercialized in powdered form is used for the treatment of gonorrhea, syphilis, staphylococcus, fibroid, gastrointestinal diseases, typhoid, malaria, infertility, fever, waist pain, chest pain, pie, amoebic dysentery, hepatitis, and rheumatism. Omega ${ }^{\circledR}$ Roots powder contains Carica papaya $(4 \%)$, Magnifera indica (15\%), Newbouidia laevis (22\%), Azadirachta indica (25\%), Jasminum officiorli (7\%), Aloe barbadensis (20\%) and Ginseng (7\%) as active ingredients. 
The aim of this study is to evaluate the possible toxic effect of Omega ${ }^{\circledR}$ Roots + Ginseng Aloe Vera herbal mixture (Omega ${ }^{\circledR}$ Roots) on the haematological parameters of healthy wistar rats.

\section{MATERIALS AND METHODS}

\section{Animals}

Healthy 20 wistar rats (average weight of $100 \mathrm{~g}$ ) were procured from the Animal House of the Faculty of Basic Medical Science, Delta State University Abraka, Nigeria. The animals were acclimatized for a period of two weeks prior to the study, and were placed on Growers' feed and clean water ad libitum. They received humane care in compliance with the ethical guide approved by the College of Health Sciences, Delta State University, Abraka, Delta State, Nigeria in accordance with the National Institute of Health (NIH) guidelines for the care and use of laboratory animals.

\section{Drugs used}

Omega ${ }^{\circledR}$ Roots + Ginseng Aloe Vera herbal powder

\section{Research design}

Animals were randomly placed into four groups of five animals each as follows:
Group 1 -- Normal Saline $10 \mathrm{ml} / \mathrm{kg}$

Group 2 - Omega ${ }^{\circledR}$ Roots $250 \mathrm{mg} / \mathrm{kg}$

Group 3 - Omega ${ }^{\circledR}$ Roots $500 \mathrm{mg} / \mathrm{kg}$

Group 4 - Omega® Roots 1000 mg/kg

The experimental animals were administered the Omega ${ }^{\circledR}$ Roots extracts orally daily for 14 days according to their body weights, after which all the animals were sacrificed using chloroform as anaesthetic and blood samples collected via cardiac puncture for haematological analysis.

Determination of haematological indices (RBC, WBC, PCV, Hb)

The method as described by Baker et al., ${ }^{8}$ was used for determining the blood cells counts and packed cell volume, while assay for haemoglobin concentration was done using the method of Ochei and Kolharkar. ${ }^{9}$

\section{Statistical analysis}

Data are expressed as Mean \pm S.E.M. (standard error of mean). The data was analysed using one-way analysis of variance (ANOVA) followed by post-hoc test (Dunnet) for multiple comparisons where appropriate using statistical package. Data from the test groups were compared with respective controls and differences at $\mathrm{p}<0.05$ were considered to be significant.

\section{RESULTS AND DISCUSSION}

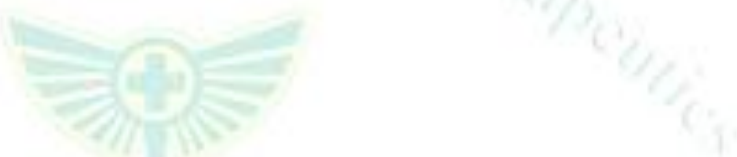

Table 1: Effect of Omega® Roots extract on body weight of Wistar rats

\begin{tabular}{|l|l|l|l|}
\hline & \multicolumn{1}{|c|}{ Initial $(\mathrm{g})$} & \multicolumn{1}{c|}{ Final $(\mathrm{g})$} & \multicolumn{1}{c|}{ \% Change } \\
\hline Normal saline & $66.80 \pm 0.25$ & $112.20 \pm 3.65$ & $68.22 \pm 5.54$ \\
\hline $250 \mathrm{mg} / \mathrm{kg}$ & $90.20 \pm 0.34$ & $131.00 \pm 5.15$ & $46.49 \pm 4.90^{*}$ \\
\hline $500 \mathrm{mg} / \mathrm{kg}$ & $102.40 \pm 0.21$ & $144.00 \pm 8.60$ & $42.36 \pm 5.91^{*}$ \\
\hline $1000 \mathrm{mg} / \mathrm{kg}$ & $96.00 \pm 0.25$ & $136.60 \pm 7.19$ & $43.69 \pm 5.94^{*}$ \\
\hline
\end{tabular}

All values are expressed as Mean \pm SEM ( $n=5)$, all data were analyzed by using one way ANOVA followed by Dunnet's test. * = $P<0.05$ was taken to be significant.

The aim of this study was to evaluate the effect of Omega ${ }^{\circledR}$ Roots + Ginseng Aloe Vera (Omega ${ }^{\circledR}$ Roots) on the haematological parameters such as red blood cell (RBC) count, white blood cell (WBC) count, packed cell volume $(\mathrm{PCV})$, and hemoglobin concentration $(\mathrm{HbC})$ of wistar rats. The results that were obtained at the end of this study clearly showed that the administration by oral route of the Omega ${ }^{\circledR}$ Roots extract non-significantly $(\mathrm{P}>0.05)$ changed the red blood cell count, white blood cell count, packed cell volume, and hemoglobin concentration of the Wistar rats that were used for this study when compared to the control group of Wistar rats that received normal saline.
There was a significant $(\mathrm{P}<0.05)$ decrease in body weight of the animals when compared to the control group (Table 1). The percentage change in body weight of the animals that received 250,500 , and $1000 \mathrm{mg} / \mathrm{kg}$ of extract were $46.49 \%, 42.36 \%$ and $43.69 \%$ respectively, which are much lower than the untreated animals with $68.22 \%$ body weight change. This is an indication that the Omega ${ }^{\circledR}$ Roots extract may be useful in management of obesity, though proper anti-lipidemic study needs to be carried out. 


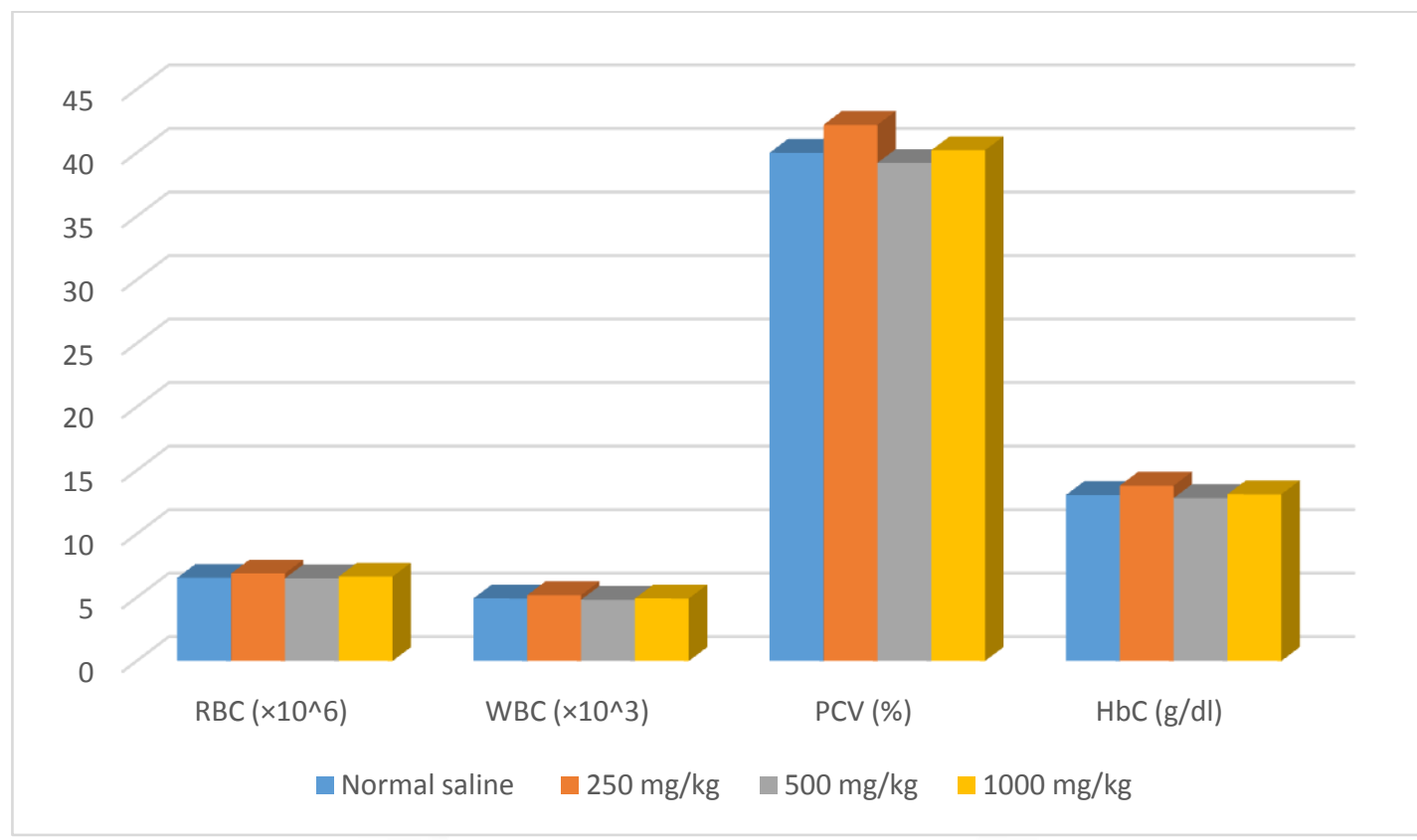

Figure 1: Graphical representation of the effect of Omega ${ }^{\circledR}$ Roots extract on haematological parameters of Wistar rats

Treated animals that received Omega® Roots extract at $250 \mathrm{mg} / \mathrm{kg}, 500 \mathrm{mg} / \mathrm{k}$ and $1000 \mathrm{mg} / \mathrm{kg}$ had a nonsignificant $(\mathrm{P}>0.05)$ change in the red blood cell count (RBC) when compared to the control group of the experimental design (Figure 1). The treated animals also had a non-significant $(\mathrm{P}>0.05)$ change in white blood cell (WBC) count when compared to the control animals. The non-significant $(\mathrm{P}>0.05)$ change observed in $\mathrm{RBC}$ count and WBC count implies that Omega ${ }^{\circledR}$ Roots extract does not affect haematopoietic process as the cells counts were relative same with that of the control group administered normal saline.

From the result of the effect of Omega ${ }^{\circledR}$ Roots extract on packed cell volume (PCV) (Figure 1), there was a non-significant $(\mathrm{P}>0.05)$ change in $\mathrm{PCV}$ level of animals in the treated group when compared to the control group. It demonstrates that Omega ${ }^{\circledR}$ Roots extract does not impair the viscosity of the blood, thus, normal flow of the blood.

\section{REFERENCES}

1. Aliyu R, Adebayo AH, Gatsing D, Garba IH. The Effect of Ethanolic Leaf Extract of Commiphora Africana (Burseraceae) on Rat Liver Functions. Journal of Pharmacology and Toxicology. 2007; 2:373-379.

2. Nostro A, Germano MP, D'Angelo A, Marino A, Cannatelli MA. Extraction methods and bioautography for evaluation of medicinal plant antimicrobial activity. Letters of Applied Microbiology. 2000; 30(5):379-385.

3. Idu M, Omogbai EKI, Amaechina FC, Ataman JE. Some cardiovascular effects of aqueous extract of the leaves of Stachytapheta jamaiciens (L) Vahl. International Journal of Pharmacology. 2006; 2:163-165.

4. Okigbo RN, Mmeka EC. An Appraisal of Phytomedicine in Africa. KMITL Science and Technology Journal. 2006; 6:8394.
Furthermore, there was a non-significant $(\mathrm{P}>0.05)$ change in haemoglobin concentration $(\mathrm{HbC})$ level in all treated group when compared to the control group (Figure 1). This result shows a blood haemoglobin concentration that is indifferent as that of the untreated animals, hence, revealing that Omega ${ }^{\circledR}$ Roots extract maintained the oxygen- and nutrient-carrying potential of the blood.

\section{CONCLUSION}

This study showed that following acute consumption of single dose of Omega ${ }^{\circledR}$ Roots + Ginseng Aloe Vera (Omega ${ }^{\circledR}$ Roots) extract daily for the treatment of ailments and diseases, there is a non-toxic effect on the blood cells. Hence, Omega ${ }^{\circledR}$ Roots + Ginseng Aloe Vera (Omega ${ }^{\circledR}$ Roots) herbal mixture is nonhaematotoxic. However, chronic administration may prove otherwise.

\section{CONFLICT OF INTEREST}

No conflict of interest.

5. Phua DH, Zosel A, Heard K. Dietary supplements and herbal medicines toxicities - when to anticipate them amd how to manage them. Int J Emerg Med. 2009; 2(2): 69-76

6. Efferth T, Kaina B. Toxicities by herbal medicines with emphasis to traditional Chinese medicine. Curr. Drug Metab. 2011; 12(10):989-996

7. Timbrell J. Principles of Biochemical Toxicology. 3rd ed. USA: Taylor and Francis Ltd; 2000.

8. Baker FI, Silverton RE, Pallister CJ. Baker and Silvertons Introduction to Medical Laboratory Technology. 7th ed. Nigeria: Bounty Press Ltd; 1998. P. 339-373.

9. Ochei J, Kolhatkar A. Complete blood count. Medical Laboratory Sciences. 6th ed. M. Graw Hill publishing company Limited; 2007. P. 273-283. 